\title{
Expecting Refugees in Latvia: Negative Stereotyping
}

\author{
Vadims Murašovs ${ }^{1}$, Aleksejs Ruža ${ }^{2}$, Vitālijs Raščevskis ${ }^{3}$, Valērijs Dombrovskis ${ }^{4}$ \\ ${ }^{1-4}$ Daugavpils University
}

\begin{abstract}
In response to a dramatic increase of illegal immigration in the European Union, in the fall of 2015 Latvia agreed to accept several hundreds of refugees on its soil. Nevertheless, Latvian society remains very sceptic about these plans, and reportedly demonstrates strong negative attitudes towards refugees. According to the survey, by the end of 2015 the factual experience of interaction with refugees did not exceed ten per cent of Latvian population. This suggests that most of the real attitudes are formed by mass media and other socialisation agents. In order to uncover the nature of these feelings, the present study has been designed to make an in-depth social psychological study on attitudes. One thousand Latvian residents evenly representing Latvia's demography have taken part in this study. A modified Stephan's Prejudicial Attitude Survey has been used to study prejudice. Negative stereotyping represents one of the emotional components of attitudes towards refugees. The results illustrate the palette of emotions and the level of their expression in Latvian society, and highlight the feelings, which may shape the identity of the in-group.
\end{abstract}

Keywords - Attitudes, emotions, negative stereotyping, prejudice, refugees.

\section{INTRODUCTION}

An established modern European nation does not only provide identities, social, economic and political rights and opportunities to its members; it also shares certain geopolitical obligations. The adaptation to the constantly changing international context is what inevitably makes a nation strongerit guarantees integrity of its nation-building process and provides sound identities to its members in a highly globalised world. The contemporary developments show that, in fact, globalisation processes do not eliminate nationhood; instead they complicate the construction of collective identities (Scholte, 1996).

The contemporary European refugee crisis has demonstrated that Europeans are not that open towards accepting new outgroups in their societies, at least not in the numbers proposed by the European Commission in autumn 2015. The plan, which was based on quotas for each EU member state, divided the Union into camps, shook its founding principle of unity in diversity, and threatened the future of the European project as such.

According to the initial plan, nearly eight hundred asylum seekers will be relocated from refugee camps in Southern Europe to Latvia during the next two years. Although this number seems insignificantly low, especially comparing it to the number of refugees in Europe, which is close to 1.5 million (UNHCR, 2015a), it appears to acquire some kind of critical mass and become a problem for the host society, i.e., a threat to its economy, culture, values, morals and identities. People seem to be sure that this is just the first wave of immigration of such kind and that they are about to witness a brand new chapter in the history of their nationhood.

The attitudes towards refugees in Latvia are predominantly negative. Eurobarometer data show that Latvian population holds the most sceptic attitudes in the whole of the EU - about $80 \%$ are against the arrival of refugees (EC, 2014). Given that in 2015 the factual experience of actual interaction with refugees reportedly did not exceed ten per cent of Latvian population (Murasovs, Ruza, Rascevskis \& Dombrovskis, 2016), the negative reaction of Latvians to the plan of the European Commission had been generally shaped by the mass media content and populism of certain politicians. The rise of nationalistic rhetoric is not unique for Latvia. It just has followed the established European pattern.

According to the Treaty of Lisbon, that came into force on 1 December 2009, the EU and the member states share competence in migration and asylum policy, which is part of a broader policy area - freedom, security and justice. However, the current EU asylum system seems not functioning properly. In January 2016, the European Commission declared that the original plan for refugee resettlement in the EU had failed, and that the Commission would present a proposal to reform the Dublin Agreement in 2016.

The United Nations High Commissioner for Refugees notes that France, Germany, Sweden and the United Kingdom have the biggest numbers of refugees in the EU (UNHCR, 2015a). Despite the levels of prosperity and progress in Europe, no European state has been reported to be among the top ten refugee-hosting countries in the world, although $7 \%$ of the total population of the EU (33 million people) are reportedly foreignborn residents. Developing countries host around $86 \%$ of all refugees in the world, which is the largest share worldwide; and the least developed countries alone provide asylum to $25 \%$ of all refugees (Ibid). Responding to the current crisis, Germany, Sweden, Italy and France provided shelter to around two-thirds of all the refugees in Europe (EMN, 2015). However, Latvia receives the lowest number of asylum applications in the EU both in relative and absolute terms (UNHCR, 2015b).

The aim of the current study is to take a closer look at the prejudice towards coming refugees among Latvian residents and determine the predicting variables of its emotional component - negative stereotyping. The research team applies the Prejudicial Attitude Survey to study this component and, based on the theoretical model that pairs intergroup theories with the theories of nationalism, hypothesises that such variables as age, gender, mother tongue, media environment, experience of interaction with refugees and foreigners, and emigrational experience have certain predictive effect on negative stereotyping. 
The term refugees in this particular study covers asylum seekers, persons with alternative status, and refugees, regardless of their means of arrival in Latvia. The term Latvians has no ethnic connotation; it refers to the population of Latvia in general - the host society, or the in-group.

\section{INTERGROUP THEORIES}

There are various explanations why some European societies, including Latvian, are striving to sustain status quo in their homelands and opposing to changes. The most suitable framework is to apply various intergroup theories in pair with theories of nationalism. Therefore, we should take a closer look at how social groups, including nations, are formed and sustained; how social identities are being developed and reproduced; and what role the processes of nation-building may play in the current refugee crisis in Europe.

Socialisation is a process in which individual is habituated to his/her society, forms cognitive and emotive attachments to it, and incorporates its features and norms into his/her identity (Hall, 1999). The Referent Informational Influence Theory explains three stages of the formation of a social group (Turner, 1982). First, individuals define themselves as members of a distinct social category. Second, they form or learn the stereotypic norms of that category. Certain appropriate, expected and desirable behaviours are used to define the category as different from other categories. Third, individuals assign these norms to themselves; their category membership becomes psychologically salient, and their behaviour becomes normative, or conformist. The stronger the identification of individual with the group, the more she will attempt to achieve intergroup differentiation (Taylor \& Moghaddam, 1987).

The Social Dominance Theory (SDT) explains how groups are formed and how individual group members behave to maintain them. The SDT reveals how groups form into hierarchies and what produces and maintains prejudice, stereotypes and discrimination. The fundamental thought of SDT is that human society is organised by group-based hierarchies, in which dominant and subordinate groups coexist. The group members are motivated to behave in ways that sustain these hierarchies and preserve their social status, justifying their group behaviour through the tripartite system that includes legitimising myths, trimorphic structure, and social dominance orientation (Redmond, 2009; Pratto, Sidanius \& Levin, 2006; Sidanius \& Pratto, 1999).

Social systems engage in a variety of social practices, which distribute social value in these systems. Legitimising myths produce and maintain group-based hierarchies by constructing attitudes, beliefs, stereotypes, values and ideologies, which, in their turn, stimulate moral, cognitive and intellectual justification for the social practices (Sidanius et al., 1999).

The universal three hierarchy systems are age, gender and arbitrary-set. The arbitrary-set system is the most relevant for our case - it is based on what the society, in which the group is based, finds or holds socially distinct in terms of power. Such systems represent the most dynamic group-based social hierarchy, and have the potential to be the most inclusive and positive in terms of being socially constructive, as well as the most exclusive, or socially destructive. Class, ethnicity and nationality are good examples of arbitrary-set (Pratto et al., 2006).

Social dominance orientation is a degree to which individuals support group-based hierarchy. This orientation is the strongest predictor of discrimination.

The Social Identity Theory (SIT) focuses on the relationship between self-concept and group behaviour, and explains how identity component motivates behaviour, according to a specific social context. The SIT predicts intergroup behaviours based on the individuals perceived status in an intergroup environment (Tajfel, 1978). It identifies three components of social identity: self-conceptualisation, group self-esteem, and commitment to the group. The result is that all other groups become out-groups - rivals for status and resources, and a source for comparison. When a perceived threat occurs, this leads to discrimination of out-groups, stereotyping and prejudice (Redmond, 2009).

The Intergroup Threat Theory (ITT) focuses on conditions that lead to threat, which, in turn, have impact on attitudes and behaviour (Wagner, 2008). The fundamental condition that leads to threats is the lack of resources, which motivates the group to compete for them in order to maintain its identity as a group or to achieve its goals (Riek, Mania \& Gaertner, 2006). According to ITT, without a threat individuals are not motivated to protect their resources and they engage in cooperative behaviours instead. In-group favouritism and out-group derogation characterise group behaviour. Intergroup threats contribute to conflict because they influence behaviours, perceptions, and emotions.

The four major threats cause conflict between groups. These are realistic threats, symbolic threats, intergroup anxiety and negative stereotyping. Realistic and symbolic threats both deal with threats to the interests of the group, while intergroup anxiety and negative stereotyping enhance perceived threats by cultivating negative expectations and opinions of other groups (Redmond, 2009). These four threats can be classified according to their interpersonal or intergroup emphasis realistic and symbolic threats measure prejudicial attitudes, which are related to the in-group as a whole, but negative stereotypes and intergroup anxiety measure fears, which are related to in-group members' perceptions of each other (Bizman \& Yinon, 2001). Realistic and symbolic threats tend to explain attitudes towards out-groups, while negative stereotypes and intergroup anxiety lack this predictive capacity (Schweitzer, Perkoulidis, Krome, Ludlow \& Ryan, 2005).

Immigrants are often perceived as a threat to resources, employment opportunities and welfare of the host community. Therefore, realistic threats are defined as threats, which challenge the welfare, political and economic power of the majority group. On the other hand, the symbolic threats challenge identities, beliefs, morals and values of the host community. These are often related to cultural, religious, linguistic differences, which threaten the social fabric of the majority community. These threats predict action tendencies relating to negative treatment (Hartley \& Pedersen, 2015). Previous studies (Kamans, Otten \& Gordijn, 2011; Riek et al., 
2006) have shown that perceived realistic and symbolic threats may increase anxiety, therefore, influencing intergroup tensions, which may culminate in discrimination or conflict.

Negative stereotypes, which the in-group develops about the out-group, are based upon attributes the in-group believes the out-group to have. They refer to the expectations concerning the behaviour of the out-group members. Stephan notes that prior relations between the groups are critical for the creation of negative stereotypes (Stephan \& Stephan, 1996).

Intergroup anxiety plays a mediator role between intergroup contact and attitudes towards out-groups. Stephan considers intergroup anxiety as another aspect of threat, which contributes to prejudice (Stephan \& Stephan, 1985; Stephan, Ybarra \& Bachman, 1999). This anxiety refers to the experience of being personally threatened during social interaction with out-group members.

The revised version of ITT (Stephan \& Renfro, 2002) distinguishes between personal threats and threats to the ingroup as a whole. It also expands the list of antecedents of threat. The current list consists of the following: strong identification with the in-group; negative personal contact with the out-group; a history of conflict between the groups; substantial disparities in status between the groups; the size of the out-group relative to the in-group within the society; social dominance orientation and self-esteem; cultural dimensions; and situational factors (Redmond, 2009).

\section{NATIONALISM}

In the previous section we have mentioned that nationalism can become the framework, which provides an intellectual justification for social practices and reproduces the social hierarchy in a given society. Kellas (1998) emphasises that nationalism is both an ideology and a form of behaviour. Nevertheless, nation as any other social group confirms to certain mechanisms and strives for its integrity and sustainable reproduction (Tajfel, 1978).

Identities do not exist outside their making; they are socially created in specific social circumstances (Renwick, 1996). Calhoun (1998) argues that identities are often personal and political projects, in which we participate, empowered by resources of experience and ability, culture and social organisation. Anderson (1998) claims that the formation of a nation is based on an idea, it is an act of imagination, and nation is an imagined community. This act is to imagine the specific group as an actual entity. In addition, national community cannot be imagined without imagining communities of foreigners, which make "our” culture unique (Özkirimli, 2000). Said enrich Anderson's definition by stressing that a nation has also to be an interpretive community, because it has to create its own history and constantly interpret itself (Scheff, 1998; Hutchinson \& Smith, 1994). Scholte (1996) notes that the closer contact with foreigners through global relations has actually not reduced but heightened awareness of, dedication to, and determination to preserve national distinctiveness.

There are two major formats for nationalism to evolve. These formats lead to fundamental differences in the nation-building processes as well as in attitudes between the in-groups and the out-groups in these societies. In Europe, states established nations and nations established states, i.e., Kulturnation in Central and Eastern Europe, where nations established states, and Staatsnation in Western Europe, where states developed nations (Hutchinson \& Smith, 1994).

The Western nationalism was the product of political and social factors. It was preceded by the formation of the national state or coincided with it. Western nationalism was closely connected in its origin with the concepts of individual liberty and rational cosmopolitanism. As a result, it stressed the political reality and was characterised as optimistic, pluralistic and rationalist. It was largely the expression of the political aspirations of the rising middle classes. The nation was regarded as a vital, existing, real thing. Political integration was sought around a rational goal. Such communities are based on interest, not on symbolic identification. Breton calls this type of nationalism political, civic, territorial, or secondary. It is also referred to as state nation. Brown emphasises that in a political nation the state claims that its people constitute a nation because they have willingly come together to form a community of equal citizens irrespective of their racial, religious or linguistic backgrounds. They are a nation because they wish and believe themselves to be a nation; and nationhood is defined in terms of the equal duties, rights and status of all citizens (Özkirimli, 2000; Hutchinson \& Smith, 1996).

The Eastern nationalism arose later and at a more backward stage of social and political development. In conflict with the existing state pattern, it found its first expression in the cultural field and sought for its justification in the "natural" fact of a community held together by traditional ties of kinship and status. The frontiers of the existing polity rarely coincided with that of the rising nationality. This type of nationalism meant collective power and national unity, independence from foreign domination or the necessity for expansion by the superior nation. It reflected the aspirations of the lower aristocracy and the masses. Since it was not rooted in a political and social reality, it lacked self-assurance and this inferiority complex was often compensated by overconfidence. The dependence on the West, which remained for a long time the model, coupled with social backwardness produced a much more emotional and authoritarian nationalism. The East was also detached from political reality, and searched for the ideal fatherland. Its nationalism was mostly concerned with myths and dreams of the future, without immediate connection with the present. Breton notes that such societies and their institutions are considered to be founded on cultural unity. This type of nationalism has been labelled cultural, ethnic, primary, or nation state (Hutchinson \& Smith, 1996; Özkirimli, 2000).

The two nationalisms had different conceptions of nation. The Western idea was that nations emerged as voluntary unions of citizens, who expressed their will in contracts, covenants and plebiscites; integration was based upon a political idea and special emphasis was laid upon the universal similarities of nations. In the East, the nation was regarded as a political unit centring around the irrational, pre-civilised folk concept, focusing on the dignity, ideals, mystery and self-sufficiency of the folk community (Özkirimli, 2000). Civic nationalism is 
often considered as an elite project "from above" - social movements and state politics aimed at national independence and national self-determination, i.e., the formation of a national state in terms of inclusion, by mobilising the maximum of potential group members "against" other nations. Ethnic nationalism, on the contrary, is often called nationalism "from below", and its major dimension is the opposition to the state itself. This nationalism reflects evaluation, rather than project, and it is aimed at the political and cultural superiority. The idea of such identity is the search of opposition, or "other" groups for the comparison, within the state (immigrants, social classes and groups), and the politics of exclusion (Treanor, 1997). The state nations tend to pursue mainly assimilative ethnic policies or, in case of considerable immigrant minorities, may result in an integrationist ethnic policy, while nation states pursue ethnic policies that are more oriented towards differentiation and segregation (Kalnins, 1997).

\section{PREJUDICIAL ATTITUDES}

According to Hogg (2006), an attitude is a relatively enduring organisation of beliefs, feelings and behavioural tendencies towards socially significant objects, groups, events or symbols. Attitudes are evaluations of certain objects; these evaluations range from extremely negative to extremely positive, although some latest perspectives (Wood, 2000) permit that individuals may hold multiple attitudes towards the same object, i.e., being conflicted or ambivalent towards it, or having both positive and negative attitude at the same time. Psychology differentiates between deliberately formed (explicit) and subconscious (implicit) attitudes. Explicit attitudes develop in response to recent information and reflect mental associations through socialisation experience. Explicit measures tend to involve bipolar scales, and rely on self-reports and observation of behaviour, while implicit measures rely on indirect measures - they are more valid and reliable, because these attitudes are assumed to be automatic and not directed consciously. One of the problematic aspects of conducting research on attitudes is that people often express socially desirable attitudes. Therefore, it is common that they hold implicit prejudicial attitudes, express explicit attitudes that report little or no prejudice at all (Whitley, 2010). Some researchers (Katz, 1960; Lapinski \& Boster, 2001) apply a functional approach to explaining attitudes, meaning that attitudes serve certain functions to individuals. Consequently, in order to change the attitudes, appeals have to be made to the functions, which these particular attitudes serve for the individual. This approach distinguishes between four different groups of attitudes, based on their functions: utilitarian, knowledge, ego-defensive and value-expressive.

The current study applies a triple attitude model, according to which attitudes consist of three components - cognitive, emotional and behavioural (Akopova \& Ruza, 2010). It states that beliefs, feelings and behaviour towards an object can influence attitudes towards it, which, in their turn, can reciprocally influence the beliefs, feelings and emotions. The model implies that a cognitive component reflects the comprehension of social attitudes, an affective component - emotional assessment of the object in hand with an expression of sympathy or antipathy towards it, but a connotative or behavioural component reflects the consecutive behaviour towards the object - meaning recognition, assessment and readiness to act.

Attitudes are expected to change as a function of personal experience. Similar to changes in social representations (Ruza, Ruza, Rascevskis, Vorobjovs \& Murasovs, 2016), attitudes are sensitive; they reflect contemporary events and adjust to new contexts and environments. The latest research in psychology focuses on responses to communication, because persuasion is one possible way to change attitudes. Obviously, the political rhetoric is profoundly influential in shaping community attitudes - shifting negative attitudes towards refugees requires a significant change in political rhetoric, political culture, social norms and media reporting (Pedersen, Watt \& Hansen, 2006). Media are definitely one of the primary factors influencing attitudes and the formation of opinions. They set agenda, tell their audience what to think; they construct ideologies, and feed to the integrity of national identities (Billig, 1995). Finney and Peach (2004) note that the key factors determining media effects include the following: the individual's perception of the source of information; prior awareness, knowledge, interest in and personal experience of the issues; the prominence of a message and its repetition; the relation of the message to the individual's existing attitudes, including whether it is confirming or challenging; the individual's views of their own attitudes, and of majority public attitudes; and how the contestation of meaning between sender and receiver is dealt with.

According to Haslam and Holland (2012), one of the personality characteristics that shape negative attitudes is "prevention focus", which means that instead of being oriented towards aspirations and opportunities, people tend to focus on possible negative outcomes, duties, obligations and security. Several previous studies (Pedersen, Attwell \& Heveli, 2005; Pedersen, Watt \& Hansen, 2006; Hartley \& Pedersen, 2015) have demonstrated that negative attitudes towards asylum seekers are often rooted in inaccurate beliefs or myths, which portray asylum seekers as a direct threat to economy, society, and national sovereignty. These myths fuel discussions about support and rights, which should be given to the asylum seekers and refugees in the host society (Verkuyten, 2004). The form of attitudinal, affective and behavioural prejudice towards immigrants is often called xenophobia. However, some scholars prefer using the term nativism instead, to emphasise the neutrality of the term, in contrast to xenophobia, which implies the presence of prejudice and fear (Yakushko, 2009). Traditional immigrant societies have long history of performing empirical studies on attitudes towards immigrants (Murray \& Marx, 2013; Suhnan, Pedersen \& Hartley, 2012; Yakushko, 2009; Finney \& Peach, 2004; Haslam \& Holland, 2012; Schweitzer, Perkoulidis, Krome, Ludlow \& Ryan, 2005); however, the current refugee crisis has demonstrated that many European nations have faced the urgent necessity for the deeper understanding of the intergroup processes in their societies and challenges to their nationhood projects. 


\section{RESEARCH OVERVIEW AND METHOD}

The survey was implemented in Latvia between September and December 2015, matching the period of time, when refugee issues were heatedly debated at various levels - legal, political, societal and media. It was the time when the Latvian government negotiated on the plans to relocate asylum seekers from refugee camps in Southern Europe, the Parliament (Saeima) adopted the new Asylum Law (2015), but the society formed its opinion on asylum issues.

\section{A. Participants}

One thousand Latvians evenly representing various population groups, in accordance with Latvia's demographic composition, voluntarily participated in this study: age (16-94, Mean $=42.81, S D=16.64)$, gender $(55.1 \%$ females, $44.9 \%$ males), residence (34.2\% Riga, $65.8 \%$ rest of Latvia), mother tongue (43.5\% Latvian, $56.5 \%$ other).

\section{B. Procedure}

The questionnaire was available in two languages - Latvian and Russian. Responding to the questions of the survey, which normally did not take longer than 15 minutes, was organised both individually and in groups. The structure of the questionnaire integrates the tripartite attitude model (cognitive, emotional and behavioural) and a set of variables. The current article focuses on the measures and results of the emotional component of prejudicial attitudes, i.e., negative stereotyping.

\section{Measures}

The pillar of the questionnaire, which includes the set of chosen variables, can be divided into two sections. The first section includes basic demographic questions, such as respondents' age, gender, mother tongue, place of residence (Riga or the rest of Latvia), employment (occupation, economy sector, and study field for students), level of education, level of income per family member. The second section is more specific. It covers the informational environment of the respondents (language of mass media, frequency of consuming the content of mass media in different languages), informs about their travel patterns, communication with foreign residents and emigrational experience (including the geography and the period of emigration). In order to introduce the sample to the issue in question (attitude to refugees), the survey offers two open questions, offering the participants to provide a subjective definition of the term refugee and list the main causes of becoming refugees. This section ends with a question on personal experience in communicating with refugees (and evaluation of such communication), and a question on personal political preferences (on the scale from far left to far right). At the end of the survey, the participants are also asked to provide personal assessment of their loyalty to the Latvian state, as well as to answer the question, whether they think that their attitudes are shared by the majority of Latvians. This last question reflects the phenomenon of false consensus (Ross, 1977), which is based on the observation that people tend to overestimate the extent to which their attitude is shared by others (Haslam \& Holland, 2012).
The emotional component of the attitudes has been assessed using two questionnaires. A modified version of the Prejudicial Attitude Survey (Stephan \& Stephan, 1993; Stephan, Stephan \& Gudykunst, 1999) has been used to study negative stereotyping of refugees. This methodology originates in ITT. The following terms have been used in the survey: hostility, admiration, empathy, superiority, disdain, approval, hatred, sympathy, rejection, curiosity. The response format consisted of 9-point Likert scale ranging from 1 (I do not feel this emotion at all; e.g., no hostility at all) to 9 (I feel this emotion strongly; e.g., extreme hostility), which required participants to indicate the extent to which they felt these items reflected their reactions towards refugees currently arriving in Latvia. Some items were reversed scored to create an index that reflects the negativity of the participants' attitude, where higher values indicated higher levels of prejudicial attitude.

The research team applied an unconventional approach to the scales of the survey. No numeric answers were provided, i.e., the participants were given an unmarked scale between two polar answers, allowing free interpretation of the scales. Supposedly, such an approach ensured more honest answers and minimised socially desirable responses. The unmarked scales were later processed according to the Likert approach.

\section{RESULTS}

Examination of the items on the prejudicial attitude scale suggested a possible two-factor breakdown of the measure: positive attitudes and negative attitudes towards refugees. This possibility was assessed by performing an exploratory factor analysis method (see Table I). A Kaiser-Meyer-Olkin of 0.799 showed the data set to be factorable. The principal component extraction using Varimax rotation method found two factors with eigenvalues greater than one. The variance accounted for by the first factor was $46.93 \%$. The variance accounted for by the second factor was $21.67 \%$, with the cumulative variance from these two factors accounting for $68.6 \%$ of the total variance in the measure. The two subscales are presented in Table I. An oblique rotation was applied supporting a moderately negative correlation between the two factors -0.67 . Upon inspection of Table I, it can be seen that the two factors consist of positive attitude items and negative attitude items toward refugees, respectively. Therefore, the bimodality of the attitude measure distribution appears to reflect two underlying factors in the scale, a measure of positive attitudes towards refugees and a measure of negative attitudes towards refugees. A measure of negative attitudes towards refugees was represented by five items: hatred, disdain, rejection, hostility, and superiority. A measure of positive attitudes towards refugees included only two items: sympathy and empathy. The rest of items were excluded from examination. Reliability analyses using Cronbach's $\alpha$ revealed that the items on the negative attitude $(\alpha=0.857)$ and positive attitude $(\alpha=0.707)$ measures had adequate internal consistency. 
TABLE I

RESULTS OF EXPLORATORY FACTOR ANALYSIS FOR THE PREJUDICIAL ATTITUDE MEASURE

\begin{tabular}{|c|c|c|}
\hline Scale items & $\begin{array}{c}\text { 1. Component } \\
\text { (Negative attitudes) }\end{array}$ & $\begin{array}{l}\text { 2. Component } \\
\text { (Positive } \\
\text { attitudes) }\end{array}$ \\
\hline Hatred & 0.873 & -0.083 \\
\hline Disdain & 0.852 & -0.081 \\
\hline Rejection & 0.779 & -0.073 \\
\hline Hostility & 0.763 & -0.157 \\
\hline Superiority & 0.715 & 0.120 \\
\hline Sympathy & -0.172 & 0.859 \\
\hline Empathy & 0.054 & 0.887 \\
\hline Eigenvalues: & 3.29 & 1.95 \\
\hline Total variance explained: & $46.93 \%$ & $21.67 \%$ \\
\hline
\end{tabular}

Note: Extraction method: Principal Component Analysis. Rotation Method: Varimax with Kaiser Normalization. Boldface indicates item loading $>0.4$.

A preliminary descriptive analysis represented in Table II indicates the means and standard deviations of the measures for both components. The results demonstrated that over $70 \%$ of participants scored above the mid-point on the prejudicial attitude scale. This percentage highlights the high prevalence of negative attitudes towards refugees in the current sample.

Three items, i.e., hatred, disdain and superiority, have the highest values on prejudicial attitude scale. These are the most typical emotions reflecting reactions of Latvian residents towards refugees currently arriving in Latvia.
TABLE II

BASICS StATISTICS FOR All MEASURES $(N=1000)$

\begin{tabular}{|l|c|c|c|}
\hline Measures & Alpha & M & SD \\
\hline Negative attitude & 0.857 & 5.50 & 2.04 \\
\hline Hatred & & 6.02 & 2.47 \\
\hline Disdain & & 5.98 & 2.47 \\
\hline Rejection & & 4.59 & 2.75 \\
\hline Hostility & & 4.97 & 2.68 \\
\hline Superiority & & 5.95 & 2.40 \\
\hline Positive attitude & 0.707 & 4.59 & 2.09 \\
\hline Sympathy & & 4.29 & 2.30 \\
\hline Empathy & & 4.89 & 2.44 \\
\hline
\end{tabular}

The next step was to perform the regression analysis in order to determine major predictors of positive and negative attitudes of Latvian residents towards refugees. Since dependent variables (positive and negative attitude scales mean values) did not estimate normal distribution parameters, binary logistic regression method was chosen, i.e., taking only variance from the first (coded with 0) and last (coded with 1) quartiles of the scales into analysis. The first model involved a total of $54.2 \%$ of participants, leaving a sample of 542 for the regression analyses in relation to negative attitude scale, and the second a total of $52.4 \%$ of participants, leaving a sample of 524 for the regression analyses in relation to positive attitude scale.

In order to determine predicting variables of prejudicial attitudes of Latvians towards refugees, two binary logistic regression models (Method $=$ Enter) were constructed, indicating the most important predictors of negative attitudes (see Table III) and positive attitudes of Latvian residents towards refugees (see Table IV).

TABLE III

Binary Logistic RegRession Model PRedicting Negative AtTitudes of LATVian Residents towards ReFugeES

\begin{tabular}{|c|c|c|c|c|c|}
\hline Variables entered & B & S.E. & $(\mathbf{E x p}) \mathrm{B}$ & $\begin{array}{c}\text { R2 } \\
(\text { Cox\&Snell) }\end{array}$ & $\begin{array}{c}\text { R2 } \\
\text { (Nagelkerke) }\end{array}$ \\
\hline Model & & & & 0.192 & 0.256 \\
\hline Gender & $-0.931 * *$ & 0.209 & 0.394 & & \\
\hline Employment & $-0.760 *$ & 0.300 & 0.468 & & \\
\hline Study & $0.674 *$ & 0.340 & 1.963 & & \\
\hline Media content (the Russian language) & $-0.466^{* *}$ & 0.088 & 0.627 & & \\
\hline Loyalty to the Latvian state & $-0.157 * *$ & 0.040 & 0.855 & & \\
\hline Political orientation & $-0.141^{* *}$ & 0.050 & 0.869 & & \\
\hline Age & $-0.017 *$ & 0.008 & 0.983 & & \\
\hline
\end{tabular}


TABLE IV

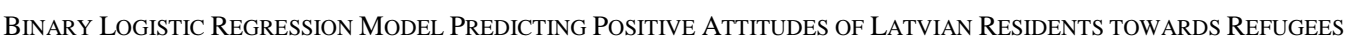

\begin{tabular}{|l|l|l|l|l|l|}
\hline \multicolumn{1}{|c|}{ Variables entered } & \multicolumn{1}{c|}{ B } & \multicolumn{1}{c|}{ S.E. } & \multicolumn{1}{c|}{ (Exp)B } & $\begin{array}{c}\text { R2 } \\
\text { (Cox\&Snell) }\end{array}$ & \multicolumn{1}{c|}{ (Nagelkerke) } \\
\hline Model & & & & 0.139 & 0.185 \\
\hline False consensus & $-1.137^{* *}$ & 0.257 & 0.321 & & \\
\hline Study & $1.192^{* *}$ & 0.347 & 2.797 & & \\
\hline Level of education & $0.430^{*}$ & 0.108 & 1.538 & & \\
\hline Political orientation & $-0.128^{* *}$ & 0.046 & 0.880 & & \\
\hline
\end{tabular}

The results show that $69.4 \%$ of predictions were accurate in the first regression model and $63.5 \%$ - in the second regression model. Both models, in general, indicate only modest improvement in fit over the baseline model. This becomes evident taking into account descriptive data, which indicate that evaluating prejudicial attitudes towards refugees Latvian residents tend to show conformity in answers and over $70 \%$ of participants scored above the mid-point of the scale. Therefore, both models could not have strong predictive value; however, they helped identify variables with a bigger predictive effect.

The first model indicates that Latvian males, who are younger, unemployed, studying, do not consume media content in the Russian language, express low loyalty to the Latvian state, support political parties standing up for bigger social guarantees, tend to express the most negative attitude towards refugees arriving in Latvia.

The second model indicates that Latvian residents, who feel certain that their opinion is not shared by the majority of the ingroup, who are studying, have higher level of education, and support political parties standing up for bigger social guarantees, tend to express the most positive attitude towards refugees arriving in Latvia.

Since being a student and a supporter of left-wing policies have a predictive effect in both models, these two variables alone cannot be considered the predictors of negative stereotyping. Instead, they have an effect only in combination with the rest of the variables in each of the models.

\section{CONCLUSION}

The aim of the current study, i.e., to discover the level of prejudice towards refugees among the Latvian residents and determine the predicting variables of negative stereotypes, has been achieved.

Although the first pillar of the survey includes a wide pool of variables, the analysis has demonstrated that only some of these have a real predictive effect on the emotional component of prejudice. These are the intensity of consuming media content in the Russian language, gender, employment and studies, political orientation, age, levels of education and loyalty to the state, as well as false consensus. It indicates that the hypothesis is partly proven.

Prior relations between the in-group and out-group are critical for the creation of negative stereotypes. According to the survey results, not more than ten per cent of Latvian population actually have experience of interaction with refugees. Therefore, it can be concluded that the prejudicial attitudes are predominantly formed by mass media and other socialisation agents.

The method of application of intergroup theories in pair with the theories of nationalism has proven to be useful. However, there is a definite need for more in-depth studies and the development of an integrated model, which could lead to a sustainable approach towards acceptance and integration of refugees in small European states, such as Latvia. Clearly, the current trends in attitudes towards refugees and the crisis as such indicate a low level of readiness of Eastern European nations to accept newcomers of different cultural backgrounds in their societies. Nevertheless, all pros and cons of this situation have to be analysed and discussed because this new wave of immigration implies not only threats to the current state of play in these societies; it also provides opportunities, which are capable of reshaping (strengthening) fragile interethnic balance, changing rigid identities, and improving their ability to cope with new contexts in a global and interconnected world. Although such crises challenge status quo in host societies, they definitely have a potential to increase the cohesion and integrity of in-groups.

\section{REFERENCES}

Akopova, I. \& Ruza, A. (2010). The Impact of EU Post-Enlargement Labour Migration on Social Attitudes of Migrant Workers: An Example of Latvia. The International Journal of Interdisciplinary Social Sciences, 5(2), 485-498. http://dx.doi.org/10.18848/1833-1882/CGP/v05i02/51592

Anderson, B. (1998). Imagines Communities: Reflections on the Origin and Spread of Nationalism. Verso.

Asylum Law. (2015). Legislation of the Republic of Latvia. Retrieved February 2016, from http://likumi.lv/doc.php?id=194029

Billig, M. (1995). Banal Nationalism. Sage.

Bizman, A. \& Yinon, Y. (2001). Intergroup and interpersonal threats as determinants of prejudice: The moderating role of in-group identification. Basic and Applied Social Psychology, 23(3), 191-196. http://dx.doi.org/10.1207/S15324834BASP2303 5

Calhoun, C. (1998). Social Theory and the Politics of Identity. In Calhoun C. (Ed.). Blackwell.

European Commission (EC, 2014). Standard Eurobarometer, 82. Retrieved February 2016, from http://ec.europa.eu/public_opinion/archives/ eb/eb82/eb82_anx_en.pdf

European Migration Network (EMN, 2015). EMN Annual Report on Immigration and Asylum 2014: A Synthesis of Annual Policy Reports 2014 submitted by EU Member States and Norway. Retrieved May 2016, from http://ec.europa.eu/dgs/home-affairs/what-we-do/networks/european _migration_network/reports/docs/annual-policy/2014/00.emn_annual_ report_on_immigration_and_asylum_synthesis_report.pdf

Finney, N. \& Peach, E. (2004). Attitudes towards asylum seekers, refugees and other immigrants. A literature review for the Commission for Racial Equality. London: Information Centre about Asylum and Refugees in the UK. 
Hall, R. B. (1999). National Collective Identity: Social Constructs and International Systems. Columbia University Press.

Hartley, L. K. \& Pedersen, A. (2015). Asylum Seekers and Resettled Refugees in Australia: Predicting Social Policy Attitude from Prejudice versus Emotion. Journal of Social and Political Psychology, 3(1), 179-197. http://dx.doi.org/10.5964/jspp.v3i1.476

Haslam, N. \& Holland, E. (2012). Attitudes towards Asylum Seekers: The Australian Experience. In Bretherton, D. \& Balvin, N. (Eds.). Peace Psychology in Australia. (pp. 107-120). Springer Science LLC. http://dx.doi.org/10.1007/978-1-4614-1403-2 7

Hogg, M. A. (2006). Social Identity Theory, in Burke, P. (Ed.). Contemporary Social Psychological Theories. Stanford University Press.

Hutchinson, J. \& Smith, A. D. (1994). (Eds.). Nationalism. Oxford Reader. Oxford University Press.

Hutchinson, J. \& Smith, A. D. (1996). (Eds.). Ethnicity. Oxford Reader. Oxford University Press.

Kalnins, V. (1997). The Citizenship Issue in the Baltic Countries: A Comparative Analysis - with Emphasis on Latvia. In Steen, A. (Ed.). Ethnicity and politics in Estonia, Latvia and Lithuania. Forskningsrapport 02/97. Institutt for statsvitenskap, Universitetet i Oslo.

Kamans, E., Otten, S. \& Gordijn, E. H. (2011). Power and threat in intergroup conflict: How emotional and behavioral responses depend on amount and content of threat. Group Processes \& Intergroup Relations, 14(3), 293310. http://dx.doi.org/10.1177/1368430210372525

Katz, D. (1960). The Functional Approach to the Study of Attitudes. Public Opinion Quarterly, 24(2), 163-204. http://dx.doi.org/10.1086/266945

Kellas, J. G. (1998). The Politics of Nationalism and Ethnicity. (2nd ed.). Macmillan Press. http://dx.doi.org/10.1007/978-1-349-26863-4

Lapinski, M. K. \& Boster, F. J. (2001). Modeling the Ego-Defensive Function of Attitudes. Communication Monographs, 68(3), 314-324. http://dx.doi.org/10.1080/03637750128062

Murasovs, V., Ruza, A., Rascevskis, V. \& Dombrovskis, V. (2016). Expecting Refugees in Latvia: Intergroup Anxiety. Social Sciences Bulletin, 2(21), 60-74.

Murray, K. E. \& Marx, D. M. (2013). Attitudes toward unauthorized immigrants, authorized immigrants, and refugees. Cultural Diversity and Ethnic Minority Psychology. 19(3), 332-341. http://dx.doi.org/10.1037/a0030812

Özkirimli, U. (2000). Theories of Nationalism: A Critical Introduction. Macmillan Press.

Pedersen, A., Attwell, J. \& Heveli, D. (2005). Prediction of negative attitudes towards Australian asylum seekers: False beliefs, nationalism, and selfesteem. Australian Journal of Psychology, 57(3), 148-160. http://dx.doi.org/10.1080/00049530500125157

Pedersen, A., Watt, S. \& Hansen, S. (2006). The role of false beliefs in the community's and the federal government's attitudes toward Australian asylum seekers. Australian Journal of Social Issues, 41(1), 105-124.

Pratto, F., Sidanius, J. \& Levin, S. (2006). Social dominance theory and the dynamics of intergroup relations: Taking stock and looking forward. European Review of Social Psychology, 17, 271-320. http://dx.doi.org/10.1080/10463280601055772

Redmond, B. (2009). Intergroup theories: How do the people around me influence me? Work Attitudes and Motivation. The Pennsylvania State University World Campus.

Renwick, N. (1996). Re-reading Europe's Identities. In Krause, J. \& Renwick, N (Eds.). Identities in International Relations. Macmillan Press. http://dx.doi.org/10.1007/978-1-349-25194-0 8

Riek, B. M., Mania, E. W. \& Gaertner, S. L. (2006). Intergroup threat and outgroup attitudes: A meta-analytic review. Personality and Social Psychology Review, 10, 336-353. http://dx.doi.org/10.1207/s15327957pspr1004_4

Ross, L. (1977). The false consensus effect: An egocentric bias in social perception and attribution processes. Journal of Experimental Social Psychology, 13(3), 279-301. http://dx.doi.org/10.1016/0022-1031(77)90049-X

Ruza, A., Ruza, I., Rascevskis, V., Vorobjovs, A. \& Murasovs, V. (2016). Safety and security in the EU: Perception of Latvian residents. Journal of Security and Sustainability Issues, 5(3), 365-375. http://dx.doi.org/10.9770/jssi.2016.5.3(5)

Scheff, T. J. (1998). Emotions and Identity: A Theory of Ethnic Nationalism, in Calhoun, C. (Ed.). Social Theory and the Politics of Identity. Blackwell.

Scholte, A. S. (1996). Globalisation and Collective Identities. In Krause, J. Renwick, N. (Eds.). Identities in International Relations. Macmillan Press. http://dx.doi.org/10.1007/978-1-349-25194-0_3
Schweitzer, R., Perkoulidis, S. A., Krome, S. L., Ludlow, C. N. \& Ryan, M. (2005). Attitudes towards refugees: The dark side of prejudice in Australia. Australian Journal of Psychology, 57(3), 170-179. http://dx.doi.org/10.1080/00049530500125199

Sidanius, J. \& Pratto, F. (1999). Social dominance: An intergroup theory of social hierarchy and oppression. Cambridge University Press. http://dx.doi.org/10.1017/cbo9781139175043

Stephan, W. G. \& Renfro, C. L. (2002). The role of threat in intergroup relations. In Mackie D. M. \& Smith E. R. (Eds.). From prejudice to intergroup emotions: Differentiated reactions to social groups. New York: Psychology Press.

Stephan, W. G. \& Stephan, C. (1996). Predicting prejudice. International Journal of Intercultural Relations, 20, 1-12. http://dx.doi.org/10.1016/0147-1767(96)00026-0

Stephan, W. G. \& Stephan, C. W. (1985). Intergroup anxiety. Journal of Social Issues, 41, 157-175. http://dx.doi.org/10.1111/j.1540-4560.1985.tb01134.x

Stephan, W. G. \& Stephan, C. W. (1993). Cognition and affect in stereotyping: Parallel interactive networks. In Macke, D. M., Hamilton, D. L. (Eds.). Affect, cognition, and stereotyping: Interactive processes in group perception. Orlando, FL: Academic Press. http://dx.doi.org/10.1016/B9780-08-088579-7.50010-7

Stephan, W. G., Stephan, C. W. \& Gudykunst, W. B. (1999). Anxiety in intergroup relations: A comparison of anxiety/uncertainty management theory and integrated threat theory. International Journal of Intercultural Relations, 23, 613-628. http://dx.doi.org/10.1016/S0147-1767(99)00012-7

Stephan, W. G., Ybarra, O. \& Bachman, G. (1999). Prejudice towards immigrants. Journal of Applied Social Psychology, 29(11), 2221-22237. http://dx.doi.org/10.1111/j.1559-1816.1999.tb00107.x

Suhnan, A., Pedersen, A. \& Hartley, L. (2012). Re-examining prejudice against asylum seekers in Australia: The role of people smugglers, the perception of threat, and acceptance of false beliefs. The Australian Community Psychologist, 24(2), 79-97. http://researchrepository.murdoch.edu.au/17603/

Tajfel, H. (1978). (Ed.). Differentiation between Social Groups: Studies in the Social Psychology of Intergroup Relations. London: Academic Press.

Taylor, D. M. \& Moghaddam, F. M. (1987). Theories of Intergroup Relations: International Social Psychological Perspectives. London: Praeger.

Treanor, P. (1997). Structures of Nationalism. Sociological Research Online, 2(1). http://dx.doi.org/10.5153/sro.70

Turner, J. C. (1982). Towards a Cognitive Redefinition of the Social Group. In Tajfel, H. (Ed.). Social Identity and Intergroup Relations. Cambridge University Press.

United Nations High Commissioner for Refugees (UNHCR, 2015a). UNHCR Global Trends - Forced Displacement in 2014. Retrieved February 2016, from http://unhcr.org/556725e69.html

United Nations High Commissioner for Refugees (UNHCR, 2015b). Integration of refugees in Latvia: Participation and Empowerment. Retrieved May 2016, from http://www.emn.lv/wp-content/uploads/ UNHCR_Integration-of-refugees-in-Latvia.pdf

Verkuyten, M. (2004). Emotional reactions to and support for immigrant policies: Attributed responsibilities to categories of asylum seekers. Social Justice Research, 17(3), 293-314. http://dx.doi.org/10.1023/B:SORE.0000041295.83611.dc

Wagner, U. (2008). Improving intergroup relations building on the legacy of Thomas F. Pettigrew. Blackwell. http://dx.doi.org/10.1002/9781444303117

Whitley, B. E. (2010). The Psychology of Prejudice \& Discrimination. Wadsworth Engage Learning.

Wood, W. (2000). Attitude Change: Persuasion and Social Influence. Annual Review of Psychology, 51, 539-570. http://dx.doi.org/10.1146/annurev.psych.51.1.539

Yakushko, O. (2009). Xenophobia: Understanding the roots and consequences of negative attitudes toward immigrants. The Counseling Psychologist, 37(1), 36-66. http://dx.doi.org/10.1177/0011000008316034 


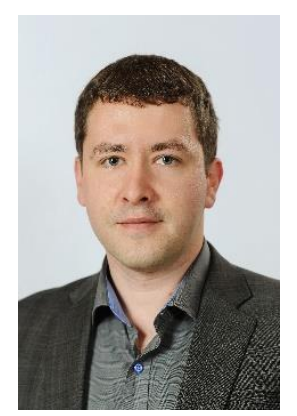

Vadims Murašovs is a $\mathrm{PhD}$ candidate in Social Psychology at Daugavpils University (Latvia); he holds the Master's degrees in International and European Relations (2007), Baltic Studies (2005), and Psychology (2005).

Vadims is a former Guest Researcher at Uppsala University (Sweden), Science Counsellor at the Ministry of Education and Science of Latvia, Specialised Attaché for Research and Space at the Permanent Representation of Latvia to the EU (Belgium), Course Instructor at Lärkkulla Folk Academy (Finland), Researcher at Daugavpils University (Latvia). He is an Associate Editor of the International Journal of Educational Organization and Leadership. His research interests are related to intergroup processes, attitudes, social identities, nationalism, migration and international relations.

2015: Gratitude of the Ministry of Education and Science of Latvia for his contribution to the development of research and space policy of the EU in the framework of the Latvian Presidency of the Council of the EU. 2015: Gratitude of the Permanent Representation of Latvia to the EU for his selfless and highly professional work during the first Presidency of Latvia of the Council of the EU. 2014: Gratitude of the Ministry of Education and Science of Latvia for his contribution to the preparation of the Latvian Presidency of the Council of the EU. He is a member of the Interdisciplinary Social Sciences Knowledge Community and a former member of the Association for the Advancement of Baltic Studies.

E-mail: vadims.murasovs@gmail.com

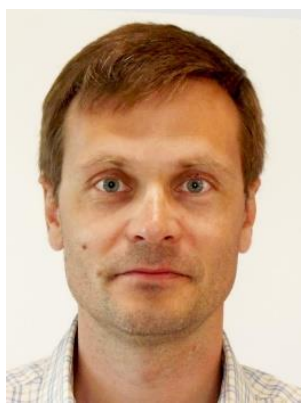

Aleksejs Ruža received his Dr. psych. degree from Daugavpils University in 2006.

$\mathrm{He}$ is an Associate Professor of Psychology, Head of psychology programmes at Daugavpils University (Latvia). Since 2011 he has been an Expert of Psychology of Latvian Academy of Sciences (Riga, Latvia) and since 2012 - an Expert of Psychology of the National Research University, Higher School of Economics (Moscow, Russia). Since 2013 he has been a Member of Editorial Board of Interpersona: An International Journal on Personal Relationships. His research interests are related to social psychology, particularly interpersonal relationship and social cognition.

E-mail: aleksejs.ruza@du.lv

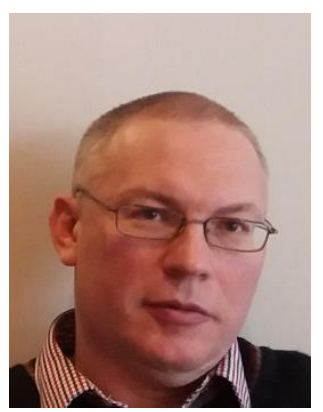

Vitālijs Raščevskis, received his Dr. psych. degree from Daugavpils University in 2011.

$\mathrm{He}$ is an Assistant Professor at the Department of Social Psychology at Daugavpils University (Latvia). Since 2015 he has been an Expert of the Latvian Academy of Sciences in the field of psychology. His research interests are related to cognitive psychology, social cognition, and psychology of interpersonal relationships.

E-mail: wiras@inbox.lv

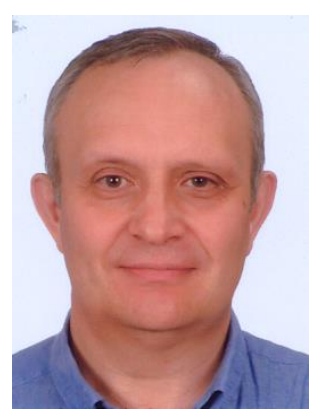

Valērijs Dombrovskis received his Dr. psych. degree from the University of Latvia in 1996. $\mathrm{He}$ is an Assistant Professor at the Department of Pedagogy and Educational Psychology, Faculty of Education and Management, Daugavpils University (Latvia), an Expert of the Latvian Council of Science in psychology and pedagogy. Since 2013 he has been a Member of the Editorial Board of Izvestiya of Saratov University (New Series: Educational Acmeology. Developmental Psychology) and Associate Editor of the International Journal of Educational Organization and Leadership, (19(2), 2013, and 22(4), 2015). His research interests are related to professional identities and sustainability issues at organisations, migration.

2010: Gratitude of Daugavpils University for his contribution in scientific development and enhancing international cooperation. He is a Member of the Latvian Sport Psychology Association.

E-mail: valerijs.dombrovskis@du.lv 